\title{
How suitable are available pharmaceuticals for the treatment of sexually transmitted diseases? (2) Conditions presenting as sores or tumours
}

\author{
R. R. WILLCOX \\ From St Mary's Hospital, London and King Edward VII Hospital, Windsor
}

SUMMARY The pharmaceutical industry is not supplying the penicillin preparations that are required for the treatment of syphilis. For those in whom penicillin hypersensitivity is suspected there is a need for a safe injectable alternative that is effective if given once daily or, preferably, at two- or three-day intervals. Existing treatments for chancroid, lymphogranuloma venereum, and granuloma inguinale are described, but even collectively there are few cases and treatments for other sexually transmitted diseases merit priority. Treatments for scabies and pediculosis pubis, although not perfect, are reasonable. There is a need for better local treatment for condylomata acuminata and systemic immunological methods, including those that increase cell-mediated immunity, deserve attention. The same is true for molluscum contagiosum. There is an urgent need for an effective, safe treatment of herpes genitalis that is able to eradicate the virus from the host. If it is proved that the herpes virus is responsible for carcinoma of the cervix this could then be the most serious sexually transmitted disease as in many countries such carcinomas are responsible for approximate seven times more deaths in women than is syphilis in men and women together. The limitations of prophylactic methods in preventing all possibility of infection with one or more of the sexually transmitted diseases are discussed.

\section{Introduction}

In the first part of this paper (Willcox, 1977) the incidence of those sexually transmitted diseases that usually present with genital discharge-namely gonorrhoea, candidosis, trichomoniasis, and nonspecific genital infection-was discussed and the treatments and needs for the future were reviewed.

This part is concerned with the less common conditions that usually present with ulcers or swellings on the genital mucous membranes or skin. In order to show the prevalence of these conditions the number of cases seen in venereal disease clinics of England and Wales in 1974 are compared with the number of cases of gonorrhoea, and also of primary and secondary syphilis.

\section{Syphilis}

PREVALENCE

Syphilis is much less common today despite recent

Presented at the Sandoz Research Institute, Vienna, 4 May 1977 Address for reprints: R. R. Willcox, MD, FRCP, Consultant Venereologist, St. Mary's Hospital, London W2

Received for publication 2 June 1977 increases in many countries, and it presents a smaller numerical problem than gonorrhoea. In England and Wales in 1974 reported cases of syphilis of all forms was only $7 \%$ in men and $4 \%$ in women compared with gonorrhoea, while for primary and secondary syphilis the figures were only $4 \%$ and $1 \%$ respectively (Fig. 1).
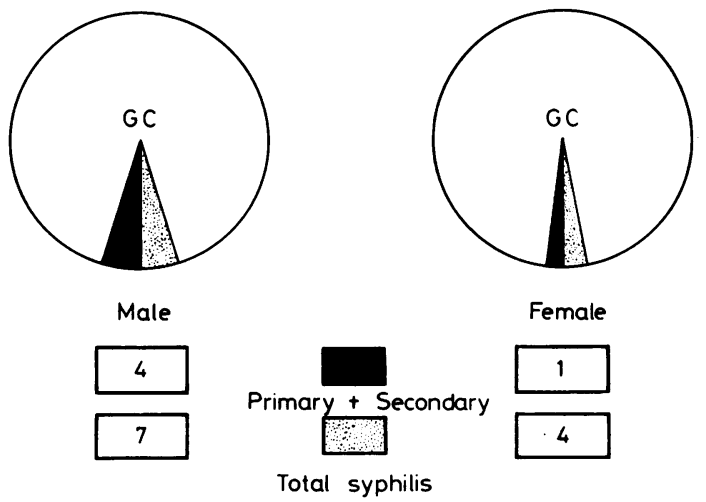

Fig. 1 Percentage of cases of syphilis compared with gonorrhoea. 


\section{TR E A T MEN T}

\section{General considerations}

Penicillin is undoubtedly the elective treatment for those not allergic to it. However as Treponema pallidum divides only slowly (every 30 to 33 hours) and penicillin exerts its effect on the dividing organism, prolonged continuous serum (and tissue) levels of penicillin must be maintained, either by multiple daily injections of crystalline penicillin $G$, single daily injections of procaine penicillin, or by weekly or twice-weekly injections of procaine penicillin with aluminium monostearate (PAM), if available, or with benzathine penicillin.

For patients in hospital a daily injection of 600000 to $1 \cdot 2$ megaunits of aqueous procaine penicillin for between eight and 15 days, depending on the stage of disease, is most suitable. For outpatients and in surgery it is better to give PAM or benzathine penicillin of which the latter, today, is the more generally available.

\section{United States Public Health Service schedules}

Recommended treatment schedules compiled by the United States Public Health Service (1976) are summarised in Table 1. They recommend benzathine penicillin, aqueous procaine penicillin $G$, and PAM with tetracycline and erythromycin (the latter for pregnant patients) for those of suspected penicillin hypersensitivity. Treatment time is generally twice as long in infections that have been present for more than one year.

Table 1 Treatment of syphilis. (United States Public Health Service, 1976)

\begin{tabular}{|c|c|c|}
\hline Preparation & Less than one year & More than one year \\
\hline $\begin{array}{l}\text { Benzathine penicillin } \\
\text { (units) } \\
\text { Aqueous procaine } \\
\text { penicillin (units) } \\
\text { PAM (units) }\end{array}$ & $\begin{array}{l}2 \cdot 4 \times 1 \\
(2 \cdot 4) \\
6000000 \text { daily } \\
\times 8(4 \cdot 8) \\
2 \cdot 4 \text { plus } 2 \times 1 \cdot 2 \\
\text { over six days } \\
(4 \cdot 8)\end{array}$ & $\begin{array}{l}2 \cdot 4 \times 3 \text { weekly } \\
(7 \cdot 2) \\
600000 \text { daily } \times 15 \\
(9 \cdot 0) \\
\text { No longer stipulated }\end{array}$ \\
\hline $\begin{array}{l}\text { Tetracycline* } \\
\text { (mg) } \\
\text { Erythromycin } \\
(\mathrm{mg})\end{array}$ & $\begin{array}{l}500 \text { every day } \times 15 \\
\text { days } \\
(30) \\
\text { ditto }\end{array}$ & $\begin{array}{l}500 \text { every day } \times 30 \\
\text { days }(60) \\
\text { ditto }\end{array}$ \\
\hline
\end{tabular}

*Contraindicated in pregnancy

These schedules have not been changed during the past decade except in the case of early congenital syphilis in which the inability of a single dose of benzathine penicillin to enter the cerebrospinal fluid has prompted much higher total doses of shorter acting penicillins to be recommended (Table 2).
Table 2 Treatment of early congenital syphilis. (United States Public Health Service, 1976)

\begin{tabular}{|c|c|c|c|c|}
\hline \multirow[b]{2}{*}{ Preparation } & \multicolumn{2}{|l|}{ Previous } & \multicolumn{2}{|l|}{ Latest } \\
\hline & $\begin{array}{l}\text { Total dose } \\
(u / k g)\end{array}$ & $\begin{array}{l}\text { No. of } \\
\text { injections }\end{array}$ & $\begin{array}{l}\text { Total dose } \\
(u / k g)\end{array}$ & $\begin{array}{l}\text { No. of } \\
\text { injections }\end{array}$ \\
\hline $\begin{array}{l}\text { Benzathine } \\
\text { penicillin }\end{array}$ & 50000 & One & 50000 & $\begin{array}{l}\text { One (if } \\
\text { cerebrospinal } \\
\text { fluid normal) }\end{array}$ \\
\hline $\begin{array}{l}\text { Aqueous } \\
\text { procaine } \\
\text { penicillin }\end{array}$ & 100000 & 10 , daily & 500000 & $\begin{array}{l}10 \text { daily or } \\
20 \text { twice daily } \\
\text { (if cerebrospinal } \\
\text { fluid abnormal } \\
\text { or not tested) }\end{array}$ \\
\hline $\begin{array}{l}\text { Crystalline } \\
\text { penicillin } G\end{array}$ & - & - & 500000 & \\
\hline
\end{tabular}

Treatments used in Europe

Generally the amounts of penicillin given for the early infection tend to be greater in Europe. For example, in only a few centres is a single injection of benzathine penicillin prescribed, the daily dose of procaine penicillin is usually in the region of 900000 to $1 \cdot 2$ megaunits and the number of twiceweekly injections of PAM after the initial epidemiological dose of $2 \cdot 4$ megaunits may be six or more.

\section{Pharmaceutical difficulties}

The treatment of syphilis is becoming increasingly more difficult largely because the pharmaceutical industry is failing to supply the necessary products, presumably as a reaction to market forces.

Crystalline penicillin $\mathrm{G}$, although freely available, has to be given several times a day and is therefore disliked for inpatient treatment of syphilis and unsuitable for outpatients. Aqueous procaine penicillin, which is particularly suitable for inpatients, is becoming difficult to obtain. In the United Kingdom the only product available is imported from Holland; it can only be purchased in large quantities so it is therefore in practice available only to hospitals. Furthermore, unlike some preparations previously on the market, it has to be suspended before use. As with gonorrhoea the situation has markedly worsened during the past decade. In 1966 there were six products of procaine penicillin available in Britain. Today there is one imported product, Table 3 .

Table 3 Difficulties in the penicillin treatment of syphilis

\begin{tabular}{ll}
\hline Preparation & Difficulty \\
\hline Crystalline penicillin G & Multiple daily injections necessary \\
Aqueous procaine penicillin & Becoming difficult to obtain \\
PAM & No longer available in many areas \\
Benzathine penicillin & Most painful \\
& Lowest serum level \\
& $\begin{array}{l}\text { Doubts on cerebrospinal fluid and } \\
\text { ocular penetration }\end{array}$ \\
\hline
\end{tabular}


For outpatients, for whom spaced injections are necessary, PAM (procaine penicillin in oil with aluminium monostearate) can no longer be obtained in many areas, including the USA and a number of European countries. A product complying with the specifications of the World Health Organisation for using in areas where treponematosis is endemic is made in Great Britain by Glaxo Laboratories, but for export only. Even the repository benethamine penicillin (Benopen-Glaxo), which did not meet such specifications, has been withdrawn.

The only suitable preparation is benzathine penicillin (Penidural-L.A.-Wyeth) which is painful for the patient, provides the lowest serum level, and penetrates less far into the cerebrospinal and ocular fluids (Table 3 ).

\section{Needs for the future}

The pharmaceutical industry spends large sums each year on research and on medical and scientific education. Venereologists would like it to make available, as a medico-social endeavour, certain products which are still active and effective but which have been withdrawn. These would include the penicillins used in injections for treating syphilis and gonorrhoea and also other diagnostic agentssuch as, Lygranum used for the now compulsorily non-available Frei skin test for lymphogranuloma venereum and the Dmelcos used for the Ito skin test for chancroid.

A safe injectable alternative is needed also for patients with suspected penicillin hypersensitivity, that is effective if given once daily, and preferably, at intervals of between two and three days.

Chancroid, lymphogranuloma venereum, and granuloma inguinale

PREVALENCE

The first and last of these three conditions, officially classified as 'venereal' in many countries, are caused
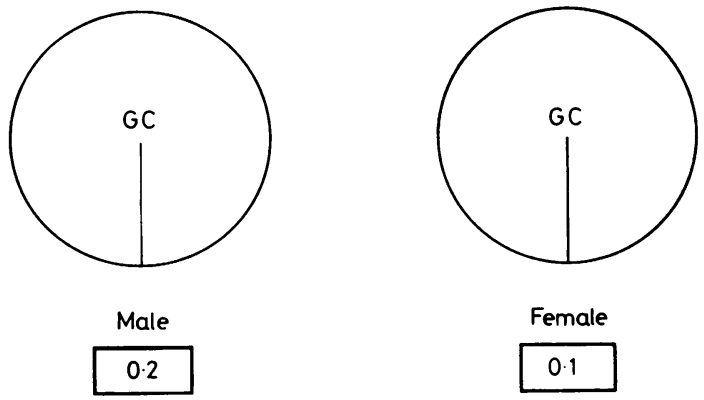

Fig. 2 Percentage of cases of chancroid, lymphogranuloma venereum, and granuloma inguinale combined, compared with gonorrhoea. by bacteria; Chlamydia are responsible for lymphogranuloma venereum. In the clinics of England and Wales, however, all three combined comprise only $0 \cdot 1-0 \cdot 2 \%$ of the numbers of cases of gonococcal infections in both sexes (Fig. 2) and one-sixteenth of the numbers of primary and secondary syphilis. They cannot therefore be considered to be important to public health in England and Wales or in northern Europe.

\section{TREATMENT}

\section{Existing treatment}

The preferred treatment for these disorders is by means of sulphonamides or antibiotics given over varying periods of time for an average of two weeks, Table 4 (Rein and Chapel, 1975; Willcox, 1975a).

Table 4 Treatment of chancroid, lymphogranuloma venereum, and granuloma inguinale

\begin{tabular}{|c|c|c|c|}
\hline $\begin{array}{l}\text { Treatment } \\
\text { agent }\end{array}$ & Chancroid & $\begin{array}{l}\text { Lymphogranuma } \\
\text { venereum }\end{array}$ & $\begin{array}{l}\text { Granuloma } \\
\text { inguinale }\end{array}$ \\
\hline $\begin{array}{l}\text { Sulphonamides } \\
\text { Tetracycline } \\
\text { Stroptomycin } \\
\text { Chloramphenicol } \\
\text { Others }\end{array}$ & $\begin{array}{l}\text { Yes } \\
\text { Yes } \\
\text { Yes } \\
\text { Yes } \\
\text { Kanamycin, } \\
\text { clindamycin, } \\
\text { metronidazole, } \\
\text { penicillin }\end{array}$ & $\begin{array}{l}\text { Yes } \\
\text { Yes } \\
\text { No } \\
\text { Yes } \\
\text { Erythromycin, } \\
\text { oleandomycin }\end{array}$ & $\begin{array}{l}\text { No } \\
\text { Yes } \\
\text { Yes } \\
\text { Yes } \\
\text { Erythromycin, } \\
\text { lincomycin, } \\
\text { ampicillin }\end{array}$ \\
\hline
\end{tabular}

Sulphonamides, with or without trimethoprim, are suitable for chancroid (soft sore) and lymphogranuloma venereum; streptomycin is suitable for soft sore and granuloma inguinale. Both tetracycline and chloramphenicol are effective in all three diseases but the latter is used only as a back-up drug because of haemopoietic toxicity.

In the treatment of chancroid there is resistance to tetracycline in parts of the Far East. Other drugs (for example, clindamycin, metronidazole, or penicillin) may also be required in the case of lesions superinfected with anaerobic organisms.

Needs for the future

As these disorders are few numerically, the treatment of other sexually transmitted diseases should be given priority.

\section{Parasitic diseases}

\section{SCABIES}

\section{Prevalence}

In clinics in the United Kingdom scabies is approximately only $6 \%$ as common in men and $2 \%$ in women as gonorrhoea (Fig.3) but it is 1.6 times and twice respectively more common than primary and secondary syphilis. 

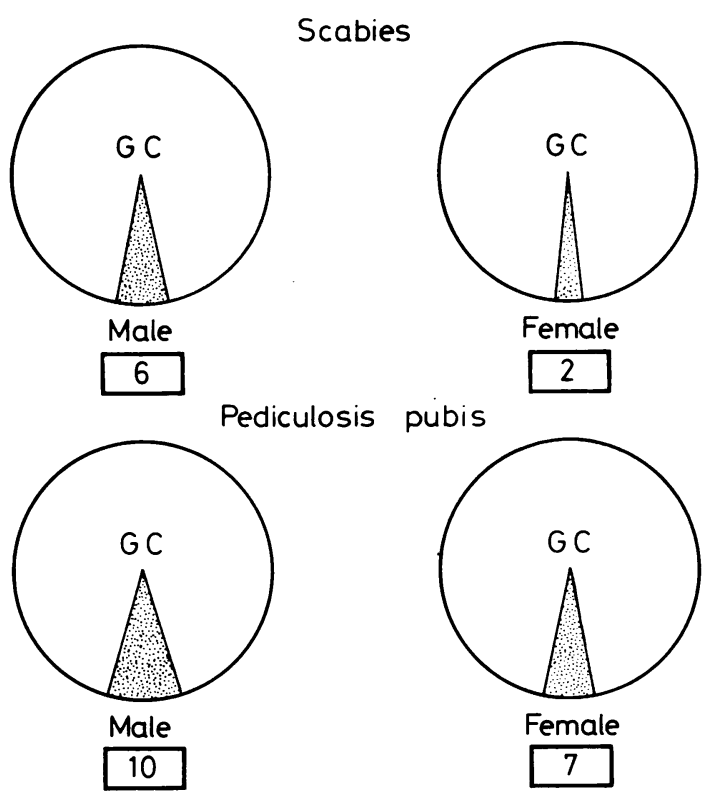

Fig. 3 Percentage of cases of scabies and pediculosis.

\section{Treatment}

Five substances are used: benzyl benzoate $(25 \%$ emulsion), crotamiton ( $10 \%$ lotion or ointment), gamma-benzene hexachloride ( $1 \%$ cream or lotion), or a lotion containing a mixture of gamma-benzene hexachloride with $1 \%$ dicophane, and monosulfiram. Two applications are generally recommended with between one and seven days between applications (Table 5).

Needs for the future

Treatments for scabies should be effective, free from adverse side effects (for example induction of dermatitis), and cosmetically and otherwise acceptable. The above treatments, if not perfect, are reasonable in these respects.

\section{PEDICULOSIS PUBIS}

\section{Prevalence}

This condition is $10 \%$ as common in men as gonorrhoea and $7 \%$ as common in women. It is 2.6 and 5.3 times, respectively, more common than primary and secondary syphilis (Fig. 3 ).

\section{Treatment}

Two at least of the substances used for the treatment of scabies (benzyl benzoate and gamma-benzene hexachloride) are also prescribed for pediculosis, for which five substances are available-that is, the above plus carbaryl, dicophane, and malathionalthough carbaryl is supplied as a shampoo purely for the treatment of head lice. Malathion and gamma-benzene hexachloride can be obtained in the form of shampoos.

Gamma-benzene hexachloride is available as a cream or lotion from two manufacturers: one recommends two treatments separated by seven days and the other recommends a single treatment (Table 6).

Table 5 Treatment of scabies

\begin{tabular}{|c|c|c|c|c|}
\hline Substance & Form & Proprietary name & Manufacturer & Applications \\
\hline Benzyl benzoate & $25 \%$ emulsion & Ascabiol & May and Baker & $\begin{array}{l}\text { Two separated by } 1-5 \\
\text { days* }\end{array}$ \\
\hline Crotamiton & $\begin{array}{l}10 \% \text { lotion and } \\
\text { ointment }\end{array}$ & Eurax & Geigy & As required \\
\hline $\begin{array}{l}\text { Gamma-benzene } \\
\text { hexachloride }\end{array}$ & $\begin{array}{l}1 \% \text { cream } \\
1 \% \text { lotion }\end{array}$ & $\begin{array}{l}\text { Lorexane } \\
\text { Quellada }\end{array}$ & $\begin{array}{l}\text { ICI } \\
\text { Stafford Miller }\end{array}$ & $\begin{array}{l}\text { Two separated by } 7 \text { days } \\
\text { Once }\end{array}$ \\
\hline $\begin{array}{l}\text { Gamma-benzene } \\
\text { hexachloride plus } \\
\text { dicophane }\end{array}$ & $\begin{array}{l}1 \% \text { of each } \\
\text { lotion }\end{array}$ & Esoderm & Napp & $\begin{array}{l}\text { Two-three daily if } \\
\text { necessary }\end{array}$ \\
\hline Monosulfiram & $25 \%$ lotion & Tetmosol & ICI & $\begin{array}{l}\text { Two to three daily: avoid } \\
\text { alcohol }\end{array}$ \\
\hline
\end{tabular}

* Makers recommend five days: for BPC equivalent one day is suggested

Table 6 Treatment of pediculosis

\begin{tabular}{|c|c|c|c|c|}
\hline Substance & Form & Proprietary name & Manufacturer & Applications \\
\hline $\begin{array}{l}\text { Benzyl benzoate } \\
\text { Carbaryl }\end{array}$ & $\begin{array}{l}25 \% \text { emulsion } \\
0.5 \% \text { shampoo }\end{array}$ & $\begin{array}{l}\text { Ascabiol } \\
\text { Derbac } \\
\text { Suleo }\end{array}$ & $\begin{array}{l}\text { May and Baker } \\
\text { Bengue } \\
\text { Jeyes }\end{array}$ & $\begin{array}{l}\text { Two separated by } 5 \text { days } \\
\text { Twice (head lice) }\end{array}$ \\
\hline Dicophane (DDT) & $\begin{array}{l}2 \% \text { application } \\
10 \% \text { dusting powder }\end{array}$ & na & $\begin{array}{l}\text { Evans Medical } \\
\text { Bush Boake and Allen }\end{array}$ & Two separated by 3-7 days \\
\hline $\begin{array}{c}\text { Gamma-benzene } \\
\text { hexachloride }\end{array}$ & $\begin{array}{l}1 \% \text { cream } \\
1 \% \text { lotion } \\
1 \% \text { lotion combined with } \\
1 \% \text { dicophane }\end{array}$ & $\begin{array}{l}\text { Lorexane* } \\
\text { Quellada* } \\
\text { Esoderm }\end{array}$ & $\begin{array}{l}\text { ICI } \\
\text { Stafford Miller } \\
\text { Napp }\end{array}$ & $\begin{array}{l}\text { Two separated by } 5 \text { days } \\
\text { One } \\
\text { Twice (head lice) }\end{array}$ \\
\hline Malathion & $0.5 \%$ liquid & $\begin{array}{l}\text { Derbac } \\
\text { Prioderm* }\end{array}$ & $\begin{array}{l}\text { Bengue } \\
\text { Napp }\end{array}$ & One \\
\hline
\end{tabular}


In the recommendations of the British National Formulary (British Medical Association, 1968) dicophane (DDT) - as a $2 \%$ application or a $10 \%$ powder-used to enjoy pride of place over benzyl benzoate but it was not in the 1976-78 edition.

Needs for the future

The same desiderata apply to these preparations as to those used for scabies.

\section{Virus diseases}

Three of the sexually transmitted diseases-namely, condylomata acuminata, molluscum contagiosum, and herpes simplex-are caused by viruses.

\section{CONDYLOMATA ACUMINATA}

Prevalence

Condylomata acuminata (venereal warts) are particularly common and usually present with sores or tumours rather than as a genital discharge. They are approximately one-third as common as gonorrhoea in both sexes (Fig. 4) and nine times more common in men and 25 times more so in women than primary and secondary syphilis.

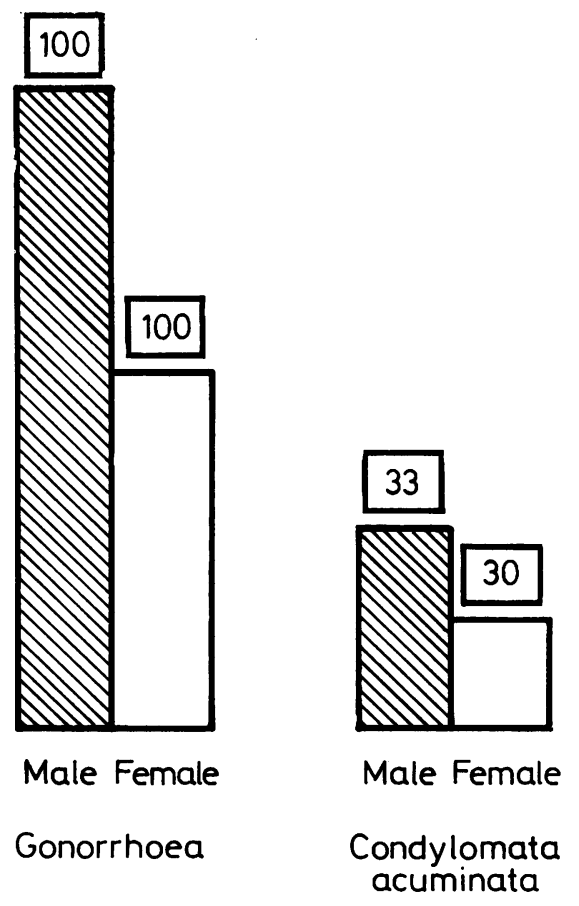

Fig. 4 Percentage of cases of condylomata acuminata compared with gonorrhoea.
Treatment (Table 7)

Physical and chemical methods In most clinics genital warts are removed or destroyed chemically or physically, or by the local application of the cytotoxic drug-podophyllin $10-25 \%$ in spirit or tincture benzoin.

Table 7 Treatment of condylomata acuminata

\begin{tabular}{|c|c|}
\hline \multicolumn{2}{|l|}{ Method } \\
\hline Physical & \\
\hline Removal & Excision, curettage \\
\hline Destruction & Cautery, electrocoagulation, cryotherapy \\
\hline Chemical & $\begin{array}{l}\text { Silver nitrate, trichloracetic acid, liquor } \\
\text { epispasticus }\end{array}$ \\
\hline Local cytotoxic drugs & Podophyllin \\
\hline Antiviral drugs & \\
\hline Local & $\begin{array}{l}\text { Idoxuridine } \\
\text { 5-Fluoruracil }\end{array}$ \\
\hline Systemic & Adenosine arabinoside? \\
\hline Immunological & Autogenous vaccine \\
\hline
\end{tabular}

Podophyllin, except in pregnancy, tends to be the treatment of first choice, followed by silver nitrate in conjunction with, or by careful application of, trichloroacetic acid (liquor epispasticus containing the blistering tincture of cantharides (Spanish fly) is now seldom used). If these are not successful the more time-consuming methods of cautery under local anaesthetic, electrocoagulation, and cryotherapy are employed. Cryotherapy is applied by dry ice pencils (seldom sufficiently effective), by an apparatus operating on nitrous oxide gas or liquid nitrogen, or by liquid nitrogen applied by swabs, metal curettes, or other objects of suitable size dipped into the liquid gas dispensed from a larger container into a vacuum flask. In pregnancy cryotherapy is preferred and podophyllin should be avoided.

In very resistant cases excision and curettage may be considered. New methods include excision under general anaesthesia with injection of a 1:1000 adrenaline solution beneath the wart which is then cut off without bleeding; the incision closes as the adrenaline is absorbed.

Anti-viral and immunological methods Anti-viral drugs are often not used in the treatment of genital warts. Idoxuridine (IDU) has been reported as being favourable in skin warts on a limited series (Oriel, 1976), but there are few reports on its use in genital warts. The substance 5-fluorouracil was used for external and intrameatal warts and had best reported results on external warts with thrice daily applications (see Willcox, 1976).

Likewise there is little experience of systemic anti-viral drugs. However, Juel Jensen (1976) reported that a child with virus-proved laryngeal papillomata went into remission after being treated 
with adenosine arabinoside. These papillomata are thought to arise from condylomata acuminata in the mother and investigations are being made on urethral papillomata.

Successful results have also been reported with autogenous vaccines ( Nel and Fourie, 1973), but some (for example, Oriel, 1976), question the wisdom of administering possible oncogenic material.

\section{Needs for the future}

There is a need for a better locally administered substance that will destroy warts but leave normal tissue, and which is non-toxic and safe to give in pregnancy.

As warts tend to proliferate in pregnancy and particularly florid examples are found in Hodgkin's disease, as in both conditions there is depressed cell-mediated immunity, immunological approaches aimed at increasing such immunity deserve investigation.

\section{MOLLUSCUM CONTAGIOSUM \\ Prevalence}

This condition is the least common of these three virus disorders-rates are only approximately one-hundredth of that for gonorrhoea in both sexes (Fig. 5). Indeed in clinics of the United Kingdom primary and secondary syphilis in men is three times and in women 1.3 times more common than molluscum contagiosum.

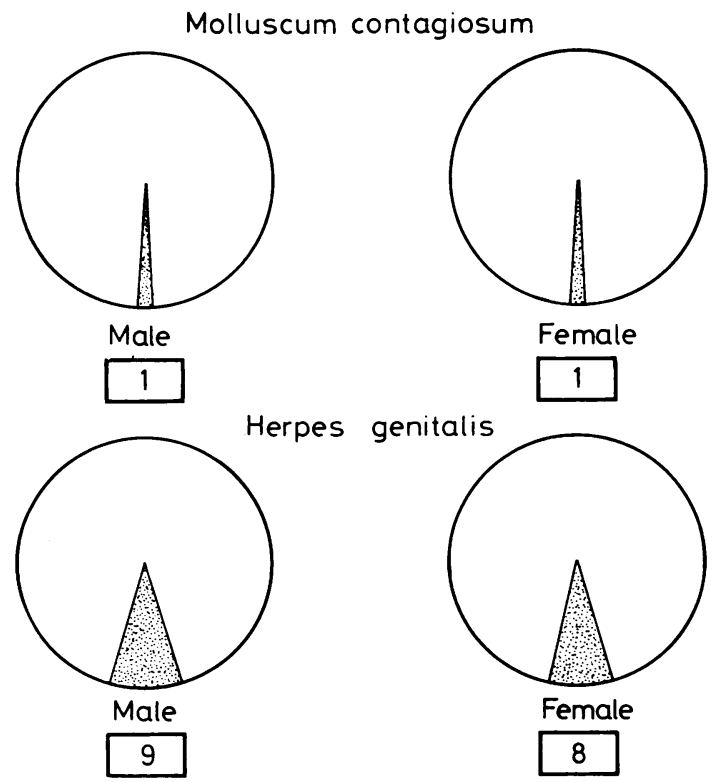

Fig. 5 Percentages of cases of molluscum contagiosum and herpes genitalis compared with gonorrhoea.

\section{Treatment}

Most of the destructive methods used locally for condylomata acuminata are also employed for molluscum contagiosum, but often with less success. However, the use of a finely sharpened wooden 'orange stick' dipped in liquid phenol and rotated under pressure in the centre of each umbilicated papule has proved useful.

\section{HERPES GENITALIS}

\section{Prevalence}

This condition is approximately $8-9 \%$ as common in British clinics as gonorrhoea in both sexes and less than one-third as common as venereal warts, but in view of its potential dangerous complications in the adult and to the newborn child, it is regarded much more seriously than many of the others (Fig. 5: Willcox, 1975b). It is 2.5 times more common than primary and secondary syphilis in men and $6 \cdot 8$ times in women.

\section{Treatment}

Local treatment The available treatment for herpes genitalis leaves much to be desired. Many antiseptic or astringent lotions and chemical or antibiotic creams have been used, some of which are listed in Table 8 (Young, 1972; Amstey, 1975; Morton, 1975; Juel Jensen, 1976; Nahmias et al., 1976). In general these alleviate local discomfort and remove secondary infection if present. One of the three, rifampicin, is reported as having some viral action.

Table 8 Herpes genitalis: local treatment

\begin{tabular}{ll}
\hline Antiseptics & $\begin{array}{l}\text { Benzalkonium chloride, boric acid, } \\
\text { potassium permanganate, povidone iodine, } \\
\text { propamidine, silver nitrate } \\
\text { Chloramphenicol, oxytetracycline, } \\
\text { rifampicin }\end{array}$ \\
Antiobiotics & $\begin{array}{l}\text { Idoxuridine } \\
\text { Idoxuridine plus DMSO }\end{array}$ \\
Organic solvents & $\begin{array}{l}\text { Surgical spirit, ether, DMSO } \\
\text { Photoinactivation }\end{array}$ \\
\hline
\end{tabular}

The first truly anti-viral agent to be used was IDU which closely resembles thymidine but gets incorporated into the DNA of the virus which consequently is unable to replicate.

Introduced first as a $0.5 \%$ ointment it was shown to be capable of shortening the healing time of recurrent herpes, but even better results were claimed when stronger concentrations of $10-40 \%$ of IDU were dissolved in dimethylsulphoxide (DMSO).

However in a recent double-blind trial on genital lesions conducted at Oxford (Morgan, 1976) DMSO without IDU did better or as well as with it. 
This confirms the good results claimed by those who use pure ether, while surgical spirit has been widely employed for years.

A more recent innovation has been that of photoinactivation. The herpetic lesions are painted with a heterocyclic dye-for example, neutral red, proflavine, or tolvidine blue-and the tissue is subsequently exposed to a white fluorescent light on several occasions. While inactivation of the herpes virus will occur there have been warnings of the possible induction of defective oncogenic herpes viruses by such means. Moreover recent claims of success have been less striking.

In many cases the lesions will heal almost as quickly with simple hygiene and local antiseptic cum analgesic preparations, as with the use of expensive treatments-for example IDU, or in the time of the patient, photoinactivation.

Systemic treatment (Table 9) Herpes genitalis is not a local disease but after the surface lesions have healed the virus retires to the nerve cells and ganglia in a state of latency. The lesions may recur after virus replication resulting from certain known and unknown stimuli. It is therefore considered by many that local treatments alone will be insufficient to cure the disease. Likewise less accessible lesions deep in the vagina or on the cervix are not amenable to local therapy.

Table 9 Herpes genitalis: systemic treatment.

\begin{tabular}{ll}
\hline $\begin{array}{l}\text { Non-specific } \\
\text { chemotherapy }\end{array}$ & $\begin{array}{l}\text { Co-trimoxazole } \\
\text { Griseofulvin } \\
\text { Metronidazole } \\
\text { Adenosine arabinoside } \\
\text { Cytosine arabinoside }\end{array}$ \\
Anti-viral substances & $\begin{array}{l}\text { Immunological mothods } \\
\text { BCCG } \\
\text { Interferon stimulation } \\
\text { Small pox vaccination } \\
\text { Herpes simplex vaccination }\end{array}$ \\
\hline
\end{tabular}

Of chemotherapeutic measures co-trimoxazole has been considered clinically to be helpful (Laird and Roy, 1975) as have also griseofulvin (Sehgal, 1974) and metronidazole (Morton, 1975). The effects of these on the herpes virus are at best only marginal.

Of anti-viral substances IDU is too toxic to be given systemically but other pyrimidine analoguescytosine arabinoside and adenosine arabinosidehave been used. Until now-for reasons of toxicity, the need to hospitalise for intravenous injections, and expense-these have been used almost exclusively on severe complicated cases-for example, encephalitis. Adenosine arabinoside is said to be effective against severe chicken pox and zoster (Juel Jensen, 1976).

Immunological methods include those that stimulate cell-mediated immunity by the use of
BCG vaccine (Amstey, 1975), stimulate interferon production by means of inactivated influenza virus, or by synthetic double-stranded RNA (Amstey, 1975). Experiments on rabbits indicate that the vaccinia virus modifies herpetic keratitis and repeated small pox vaccinations to prevent recurrences in obstinate cases have been tried from time-to-time for more than 40 years.

The ultimate hope is in a herpes vaccine itself. Söltz-Szöts (1971), in Vienna, reported that three-quarters of more than 500 patients treated ceased to have recurrences of herpes, including genital herpes.

So far there has been a lack of evaluation of the European (Diamant or Lupidon) and American (Lilly) inactivated vaccines and the possible mechansims of action have not yet been ascertained. However, the fear of carcinogenic risk of inactivated or live attenuated or mutant viruses-if the virus is indeed causally related to some human cancershas led to investigating the possibility of using DNA-free virus proteins (Nahmias et al., 1976).

\section{Needs for the future}

There is an obvious need for an effective and safe treatment of herpes that will eradicate the virus. One difficulty in assessing the results of any treatment of herpes is the wide range of natural behaviour of the disease. It is said that $50-75 \%$ of patients will have fewer recurrences of oral herpes virus infections after psychotherapy alone (Amstey, 1975).

\section{Prevention of venereal disease}

The present state of venereal disease prophylaxis can be summed up in one, if long, sentence. Venereal disease can be prevented if before sexual intercourse the man applies a condom, the woman an antispetic cream, and if afterwards the man immediately passes water and annoints his genitalia with a prophylactic ointment while the woman has a prophylactic douche: both should then have a bath before spraying each other with an antiseptic lotion, and they should visit a physican to receive 2.4 megaunits of procaine penicillin by injection plus $1.0 \mathrm{~g}$ of probenecid by mouth-which should prevent gonorrhoea and syphilis-plus a 10-day course of oral tetracycline to prevent non-gonococcal urethritis and a one- or two-day course of metronidazole or nimorazole against trichomoniasis-even with such commendable caution the risk is not entirely removed of infection from the viruses of condylomata acuminata, molluscum contagiosum, or even that of hepatitis B: neither would it be beneficial for venerophobia! 


\section{References}

Amstey, M. S. (1975). Genital herpes virus infection. Clinical Obstetrics and Gynecology, 18, 89-100.

British Medical Association (1968). British National Formulary, p. 166 Juel Jensen, B. E. (1976). Antiviral compounds with special reference to genital herpes. In Sexually Transmitted Diseases. Edited by R. D. Catterall and C. S. Nicol. Academic Press, London.

Laird, S. M., and Roy, R. B. (1975). Treatment of primary attacks of genital herpes with cotrimoxazole. British Journal of Clinical Practice, 29, 37-42.

Morgan, J. (1976). 5 IDU in DMSO, and DMSO alone in the treatment of genital herpes. Paper presented to the Medical Society for the Study of Venereal Diseases, London.

Morton, R. S. (1975). Herpes genitalis. In Recent Advances in Sexually Transmitted Diseases, pp. 325-335. Edited by R. S. Morton and J. R. W. Harris. Churchill Livingstone: Edinburgh.

Nahmias, A. J., Josey, W. E., Naib, Z. M., and Visintine, A. M. (1976). Genital herpes. In Sexually Transmitted Diseases, pp. 135-151. Edited by R. D. Catterall and C. S. Nicol. Academic Press: London.

Nel, W. S., and Fourie, E. D. (1973). Immunotherapy and 5\% topical 5 -fluoro-uracil ointment in the treatment of condylomata acuminata. South African Medical Journal, 47, 45-49.

Oriel, D. (1976). Genital warts: The clinical problems. In Sexually Transmitted Diseases, pp. 186-194. Edited by R. D. Catterall and C. S. Nicol. Academic Press: London.
Rein, M. F., and Chapel, T. A. (1975). Trichomoniasis, candidiasis and the minor venereal diseases. Clinical Obstetrics and Gynecology, $18,73-88$.

Sehgal, V. N. (1974). Letter: Griseofulvin therapy in Herpes progenitalis: A double-blind controlled trial. British Journal of Venereal Diseases, 50, 80.

Söltz-Szöts, J. (1971). Neue Methoden bei der Behandlung der Viruserkrankungen der Haut. Zeitschrift für Haut- und Geschlechtskrankheiten, 46, 755-760.

United States Public Health Service (1976). Recommended Schedules for the Treatment of Syphilis. Center for Disease Control: Atlanta. Willcox, R. R. (1975a). Chancroid, lymphogranuloma venereum, and granuloma inguinale. In Recent Advances in Sexually Transmitted Diseases, chapters 15-17. Edited by R. S. Morton and J. R. W. Harris. Churchill Livingstone: Edinburgh.

Willcox, R. R. (1975b). Importance of the so-called 'other' sexually transmitted diseases. British Journal of Venereal Diseases, 51, 221-226.

Willcox, R. R. (1976). Perspectives in venereology 1974. Abstracts of Hygiene, 51, 237-292.

Willcox, R. R. (1977). How suitable are available pharmaceuticals for the treatment of sexually transmitted diseases? I. Conditions presenting as genital discharges. British Journal of Venereal Diseases, 53, 314-323.

Young, A. W. (1972). Herpes genitalis. Medical Clinics of North America, 56, 1175-1192. 